\title{
Body Condition and Survival of Vagrant Long-billed Murrelets, Brachyramphus perdix, in North America
}

\author{
Spencer G. SEAly ${ }^{1}$ and Harry R. CARTER ${ }^{2}$ \\ ${ }^{1}$ Department of Biological Sciences, University of Manitoba, Winnipeg, Manitoba R3T 2N2 Canada \\ ${ }^{2}$ Carter Biological Consulting, 1015 Hampshire Road, Victoria, British Columbia V8S 4S8 Canada
}

Sealy, Spencer G., and Harry R. Carter. 2012. Body condition and survival of vagrant Long-billed Murrelets, Brachyramphus perdix, in North America. Canadian Field-Naturalist 126(1): 6-14.

From 1979 through 2009, 81 records of long-distance vagrancy in the Long-billed Murrelet (Brachyramphus perdix) in North America south of Alaska were examined to assess body condition and survival after first observation. Sixty-one records were of live birds, of which $38(62.3 \%)$ were discovered at sea along the west coast of North America, $18(29.5 \%)$ were encountered inland, and $5(8.2 \%)$ were encountered along the Atlantic coast. Fifteen of the 20 individuals salvaged (19 adults, 1 juvenile) were discovered on lake shores (75.0\%) and the other 5 (25.0\%) on marine coasts; $85.0 \%$ were dead when initially found (15 dead, 2 shot), and 3 (15.0\%) were moribund ( 2 died within one day, 1 later released). Of 10 sexed individuals, 5 were adult males, 4 were adult females, and 1 was a juvenile female. Eight of 10 murrelets observed foraging were diving on lakes, but 2 others surfaced with fish; two species of common freshwater fish were removed from stomachs of 2 birds shot by hunters. Most birds $(72.1 \%, n=61)$ disappeared after one observation, which suggests survival and moving on; one bird stayed at the same location for at least 25 days before disappearing. Dead or dying Long-billed Murrelets found on shorelines of fresh water may have been too emaciated to regain lost mass after arrival-they weighed less than those shot, presumably because they were not able to locate prey or too weak to capture it. Survival for weeks or longer on freshwater stopover sites better explains how Long-billed Murrelets move across North America, with some reaching the Atlantic Ocean. Long-surviving vagrants may establish a new breeding population of Long-billed Murrelet on the west coast of North America.

Key Words: Brachyramphus perdix, Long-billed Murrelet, body condition, freshwater habitat, foraging, length of stay, marine habitat, prey, stopover sites, survival, vagrancy.

What are the fates of vagrant birds? Almost a century ago, Grinnell (1922) pondered this question, wondering whether all vagrants (or "accidentals", as they were usually called then) perished or some individuals founded new populations. Data on survival of vagrants and return to populations of origin have been gathered, mainly through banding of land birds, at widespread localities in Europe (Newton 2008) and at Southeast Farallon Island, about $43 \mathrm{~km}$ west of San Francisco, California (DeSante 1973; DeSante and Ainley 1980). Some authors have considered the implications of vagrants in the dynamics of bird populations (e.g., DeSante 1983; Patten and Marantz 1996; Fraser 1997; Veit 1997; Newton 2008), but short-term survival of obligate marine birds inland with possible eventual return of individuals to the sea, and possibly home, has not been considered.

More than 80 records of long-distance vagrancy in the Long-billed Murrelet (Brachyramphus perdix), which breeds in eastern Russia, have been reported since the first specimen was taken in North America, in 1979 (Sealy et al. 1982, 1991; Mlodinow 1997; Svingen 2009). At that time, and through the mid-1990s, this form was recognized as a subspecies of the Marbled Murrelet (B. marmoratus), that is, Brachyramphus marmoratus perdix, until Friesen et al. (1996), using molecular techniques, confirmed it to be a species, as originally described by Pallas in 1811 (Stejneger 1886). Vagrancy has not been reported in the Marbled Mur- relet beyond its normal range in western North America, before or since 1979, despite careful scrutiny of all out-of-range murrelets encountered by birders and other field workers (see Svingen 2009). The recentness of the vagrancy of the Long-billed Murrelet appears to reflect in part enhanced prevailing westerly winds across the North Pacific Ocean during warm phases of the Pacific Decadal Oscillation (Sealy et al. 1991; Mlodinow 1997; Carter et al. 2011).

Long-billed Murrelets breed in eastern Russia from the northern Sea of Okhotsk and Karaginsky Gulf in the southwestern Bering Sea $\left(\sim 60-63^{\circ} \mathrm{N}\right.$; Kamchatka Krai [territory]) south to Vladivostok $\left(\sim 43^{\circ} \mathrm{N}\right.$; Primorsky Krai) (Gaston and Jones 1998; Kondratyev et al. 2000), but individuals have been reported in coastal waters in winter as far south as southern Japan $\left(\sim 30^{\circ} \mathrm{N}\right)$ (Nelson et al. 2002). The size of the global breeding population is not accurately known but is likely less than 10000 breeding pairs (Kondratyev et al. 2000).

An intriguing aspect of vagrancy by the Long-billed Murrelet is that some individuals are emaciated and apparently die soon after arriving in North America, whereas others are in better condition and, if feeding opportunities are located, they replenish their reserves and move on, possibly eastward as far as the Atlantic Ocean, or back to the Pacific Ocean. Long-billed Murrelets are known to feed on fresh water year round (Konyukhov and Kitaysky 1995; Oka and Hamosoto 2001); therefore, the key to their survival inland is find- 
ing a body of water with suitable prey on which to feed while also avoiding predators.

To gain a better understanding of survival for extended periods by vagrant Long-billed Murrelets, inland or at sea, we compiled (1) observations of foraging, prey capture, and prey taken by vagrants; (2) information on body condition of birds found dead or living when first encountered; and (3) data on length of stay and, hence, survival of birds that were alive when initially encountered. We assessed the potential for survival and successive movements of vagrants that might explain occurrence of some individuals along the east coast of North America. We also consider the possibility of long-term survival and establishment of a new breeding population on the west coast of North America.

\section{Methods}

\section{Records of vagrants}

In North America, observers now distinguish between the Long-billed Murrelet and the resident Marbled Murrelet of the west coast on the basis of differences in plumage (some differences are subtle, particularly in the fall and early winter) and the larger size of the Long-billed Murrelet (e.g., Sibley 1993; Erickson et al. 1995; Mlodinow 1997; Lethaby 2000; Maumary and Knaus 2000; Thompson et al. 2003; Svingen 2009). In one case, the identity of a Longbilled Murrelet, salvaged in New Mexico, was confirmed by molecular analysis (Witt et al. 2010). For this paper, we examined reports of Long-billed Murrelets in North America through 2009 (Svingen 2009) from the west and east coasts and the interior of North America.

We compiled information on use of marine and freshwater habitats by vagrant Long-billed Murrelets from (1) published accounts of occurrences in North America (see summaries and literature cited in Sealy et al. 1982, 1991; Mlodinow 1997; Svingen 2009); (2) persons who originally observed and/or salvaged specimens; and (3) managers of collections with specimens of Long-billed Murrelet. Data from records with insufficient documentation and records from the Bering Sea, the Aleutian Islands, and Europe were not included in our compilation (Mlodinow 1997; Maumary and Knaus 2000; Hopkins et al. 2006; Svingen 2009). Museums from which information referred to in this paper was obtained are listed in the acknowledgements and in Tables 2 and 3. Minimum straight-line distances of travel were determined using Google Maps.

\section{Body condition and length of stay}

Data on sex, age, mass, and body condition were derived from information in published reports of occurrences and from labels on specimens and information in museum catalogues. Ages were reported as (1) "adults" (after-hatching-year (AHY) birds), or (2) "juveniles" (hatching-year (HY) birds). We hypothesized that individuals found dead were exhausted after a long flight and were too emaciated to exploit prey, even if available, and therefore would weigh less. By contrast, birds that were shot apparently were healthy enough to feed after finding water and had thus regained lost mass; these birds were expected to weigh more. Body mass (nearest $0.1 \mathrm{~g}$ in most cases) was usually measured after birds had been frozen, in some cases for weeks or more. We compared body mass of Long-billed Murrelet vagrants to Long-billed Murrelets weighed in Russia (Konyukhov and Kitaysky 1995).

The date of arrival of a Long-billed Murrelet at a particular location was usually uncertain, as it is for many vagrants (e.g., Armistead and Iliff 2003). Because we did not know how long individuals had been present at their original sites before disappearing, the length of stay was recorded as a minimum number of days. For example, we considered a Long-billed Murrelet first observed on day one but gone the next or, in some cases, if no further observations were made, to have spent a minimum of two days at that location (the bird likely was present for at least 12-24 hours before the first observation and for at least another 12-24 hours before departing, without being observed the next day, and so on). Vagrants probably did not spend fewer than 24 hours at one location, unless they were disturbed or they died.

\section{Foraging on fresh water and prey consumed}

Using the literature and museum specimens, we summarized details of observations of vagrant Longbilled Murrelets foraging on fresh water and at sea and, when available, included information on prey removed from digestive tracts (hereafter "stomachs"). We accepted authors' descriptions of the following behaviour as evidence of foraging and/or feeding: (1) diving, often repeatedly, which some authors interpreted as feeding (some also construed from this activity that the bird was in good condition), and (2) birds surfacing with and swallowing a fish. Prey items removed from stomachs of birds found dead or shot by hunters provided further evidence of feeding.

\section{Results}

\section{Records of vagrants}

Excluding two early coastal records from Alaska, in 1845 and 1897 (Mlodinow 1997; also see Svingen 2009), the Long-billed Murrelet was not reported in North America until 1979, when an adult was shot by a hunter in southern Quebec (Sealy et al. 1982, 1991). Eighty-one records in North America (south of Alaska) were available from 1979 through 2009 (20 specimens and 61 sightings; Table 1).

Thirty-eight live individuals $(62.3 \%)$ were discovered at sea along the west coast of North America, from Washington $\left(\sim 48^{\circ} \mathrm{N}\right)$ to California $\left(\sim 38^{\circ} \mathrm{N}\right) ; 18$ $(29.5 \%)$ were encountered inland and $5(8.2 \%)$ were found along the Atlantic coast from Newfoundland and Labrador $\left(\sim 48^{\circ} \mathrm{N}\right)$ to Florida $\left(\sim 27^{\circ} \mathrm{N}\right)$. One of the 5 specimens salvaged at sea was from California, and the other 4 were from Florida (Tables 1 and 2). Fifteen 
TABLE 1. Habitat type of 81 vagrant Long-billed Murrelets salvaged or observed in North America south of Alaska.

\begin{tabular}{lccc}
\hline \hline & & Records & \\
\cline { 2 - 4 } Habitat type & Observation made & Specimen collected & Total \\
\hline Ocean & $43^{\mathrm{a}}$ & $5^{\mathrm{b}}$ & 48 \\
Freshwater lake & $13^{\mathrm{c}}$ & $10^{\mathrm{c}}$ & 23 \\
Reservoir/dam & 1 & 0 & 1 \\
River/creek & 4 & 0 & 4 \\
Street/road/railway tracks & 0 & 4 & 4 \\
Brine pool & 0 & 1 & 1 \\
Total & 61 & 20 & 81 \\
\hline \hline
\end{tabular}

a Thirty-eight birds, including 36 individuals and one case with two birds together (treated as separate records) were observed within $1 \mathrm{~km}$ of shore along the coast of Washington, Oregon, and California, and single individuals were observed in each of Newfoundland and Labrador, Massachusetts, New Jersey, South Carolina, and Florida.

${ }^{\mathrm{b}}$ One bird was salvaged from the coast of California, one from the Atlantic coast of Florida, and three from the Gulf coast of Florida.

${ }^{\mathrm{c}}$ One bird was salvaged from a marsh near the ocean in Massachusetts.

of 20 specimens $(75.0 \%)$ were salvaged inland, most on lake shores (Table 1); most of these 20 (85.0\%) were dead when salvaged (15 found dead, 2 shot) and the other $3(15.0 \%)$ were moribund (2 died within one day, 1 was later released). These 20 specimens were aged as follows: $95.0 \%$ were adults and $1(5.0 \%)$ was a juvenile (12 of these specimens are included in Table 2). Five of 10 individuals sexed were adult males, 4 were adult females, and 1 was a juvenile female (all sexed specimens are included in Table 2).

\section{Body condition and length of stay}

Mass of 8 vagrants found dead $(n=7)$ or found alive but died the next day $(n=1)$ averaged $193.7 \mathrm{~g}$ (SD 20.6, range 154.2-217.8) (Table 2). Seven were adults; the single juvenile weighed $207.2 \mathrm{~g}$, near the upper end of the range of body mass for adult vagrants. All masses were below the mean of Long-billed Murrelets reported from Russia-295.8 g (range 258-357) (sample size and season unknown) (Konyukhov and Kitaysky 1995). Authors variously described vagrants found dead as emaciated with no subcutaneous fat, with empty and shrivelled (flaccid) digestive tracts, and with relatively low body weights (Table 2). We assumed dead birds found on lake shores were too emaciated to be able to feed after arrival. Most grounded Longbilled Murrelets also probably soon died, regardless of condition; however, one grounded bird was rescued and released to fresh water. Two adults shot in November weighed $285.9 \mathrm{~g}$ with "... considerable subcutaneous fat" (Canadian Museum of Nature 69845; Sealy et al. 1982: 779) and $303.8 \mathrm{~g}$ (Smithsonian National Museum of Natural History 582506; Mumford 1982: 191). These values are $68.1 \mathrm{~g}$ and $86.0 \mathrm{~g}$ more than the heaviest bird found dead (217.8 g; Table 2), respectively. These individuals had fed before being shot (Table 2) and may have survived inland for many days or weeks. Many individuals encountered inland apparently attempted to forage before moving on after the observation was made.
The most frequent minimum length of stay was 2 days $(72.1 \% ; n=61$ records), equivalent to a "one-daybird" of Fraser (1997: 100). Most individuals were gone the day following first observation, having moved either to another part of the same body of water or elsewhere. Some individuals $(9.8 \%)$ stayed for at least 3 or 4 days, and the longest minimum stay was 25 days. Some vagrants that moved on apparently were observed elsewhere, i.e., were observed more than once. For example, a bird observed in coastal South Carolina on 19 November 1994 was gone the next day (Davis 1995), but three weeks later (9-11 December) an individual with similar plumage was photographed on a reservoir about $250 \mathrm{~km}$ directly north, in North Carolina (Davis and Carter 1996). The bird recovered at the edge of a marsh just inland from the coast of Massachusetts in September 1982 was molting and flightless (Table 2), which suggests arrival in eastern North America at least 1-2 weeks earlier, before its wing molt rendered it flightless (see Carter and Stein 1995).

Complicating our attempts to identify other possible re-sightings, however, is the clustering of many inland records in time and space. During intense El Niño conditions in July and August 1983, for example, three birds were found dead at Mono Lake, California, and one at Railroad Lake, Alaska (Sealy et al. 1991). In March-December 1994 and July-November 1996, 10 and 5 records, respectively, were scattered across North America from the west coast to Florida (Mlodinow 1997). In any case, the short length of stay recorded for most individuals and the low number later found dead suggest that a high proportion moved on after they were first observed.

\section{Foraging on fresh water and prey consumed}

Fish of freshwater origin removed from stomachs and observations of ingestion of fish confirmed feeding by Long-billed Murrelets at inland bodies of water (Table 3). Both of the individuals shot by hunters had consumed multiple individuals of at least two genera of 


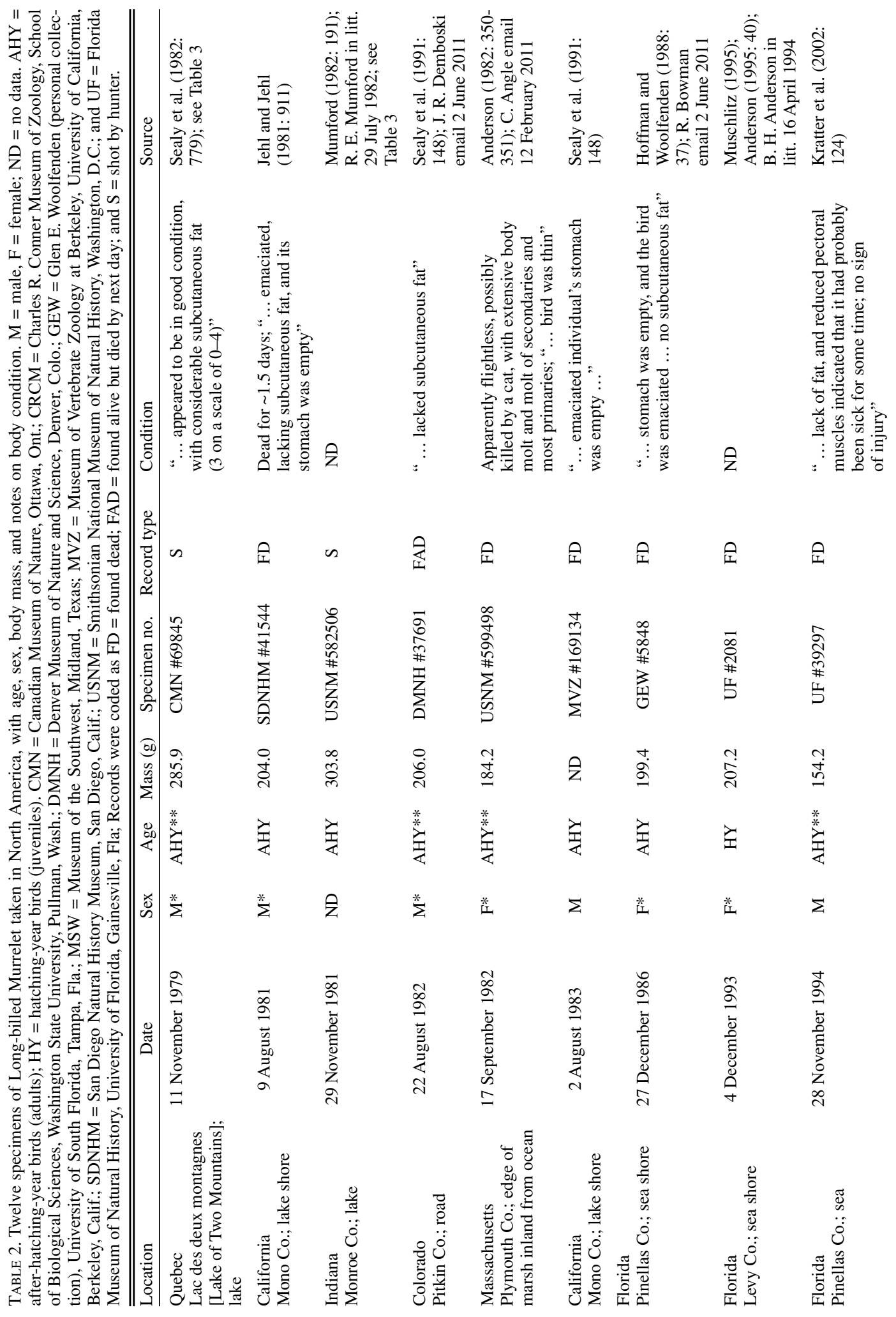




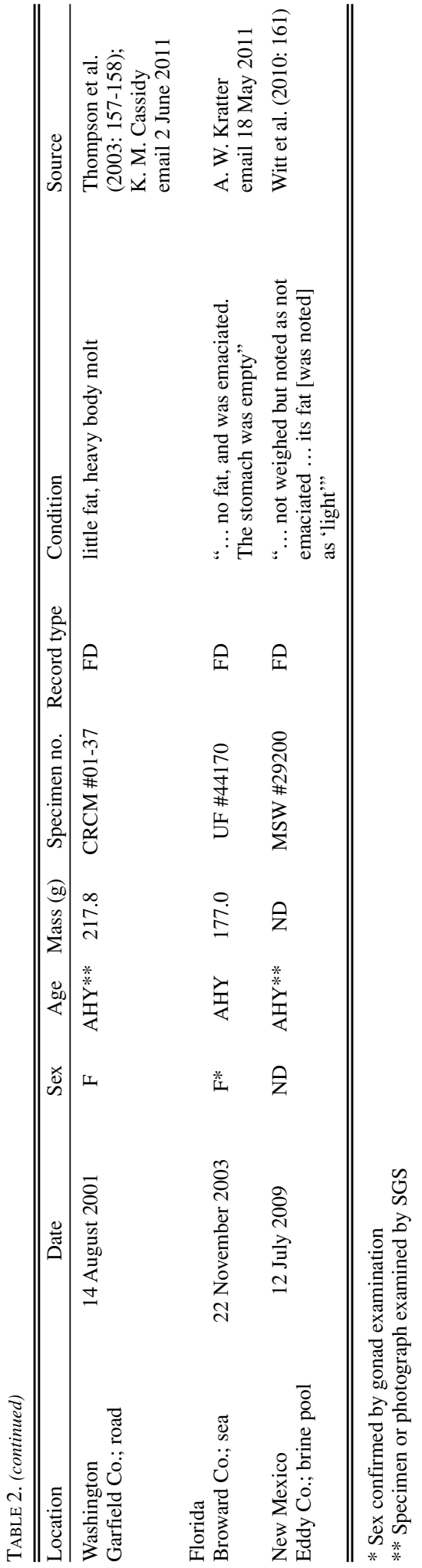

freshwater fish (Table 3), which could have been taken where the birds were shot (southern Quebec (Sealy et al. 1982) and northern Indiana (Mumford 1982)) or from previous foraging sites (Table 3). The two fish species identified-Emerald Shiner (Notropis atherinoides) and Gizzard Shad (Dorosoma cepedianum) - are common and widely distributed in freshwater habitats in central and southeastern North America (Scott and Crossman 1973). Long-billed Murrelets surfacing with fish on the Moses Saunders Power Dam, St. Lawrence River (Di Labio 1996), and a reservoir in Ohio (Fazio and Webb 1997), in addition to prey identified above, lend credence to equating "repeated dives," described by several observers, to foraging dives (Table 3). The condition of the Long-billed Murrelet observed foraging at sea off Florida (Muschlitz 1995) apparently was adequate for survival after crossing an ocean and a continent, possibly facilitated by successive stopovers, regardless of the direction travelled from eastern Russia.

\section{Discussion}

Long-billed Murrelets travelled at least $4700 \mathrm{~km}$ from the nearest breeding area in Karaginsky Gulf (northeast Kamchatka) to Cape Flattery, Washington, and some individuals survived long enough to continue southeast across North America, reaching Florida, which would be another $4600 \mathrm{~km}$ (to Miami). Travel across North America along a roughly northwest to southeast pathway from Washington to Florida was probably facilitated by a continuation of the winds and storms that initially carried individuals from eastern Russia to the west coast of North America (from Washington to northern California), followed by successive stopovers once in North America (Sealy et al. 1991).

Length of stopover likely depended on the degree of emaciation, availability of prey at the site, and presence of predators, as various lengths of stay were reported. However, three of four individuals salvaged in Florida were underweight (Table 2) and, no doubt, in poor condition when recovered, regardless of whether they had fed along the way. Survival appeared greater for individuals found farther north along the east coast, from Virginia to Newfoundland and Labrador, in the cooler waters of the southern Labrador Current. These individuals may have altered course along the Washington -Florida pathway, possibly assisted by changes in wind direction or other conditions in certain years, and more easily found prey along the way.

We assumed that vagrants did not come to North America directly from Europe, although Maumary and Knaus (2000) hypothesized a direct route from Asia to Europe to explain the occurrence of a Long-billed Murrelet in Switzerland. We would have expected many more Long-billed Murrelets to have been reported inland in Europe or on the coast, and along the east coast of North America, if the direction of travel had been westward from eastern Russia, across Europe, and across the Atlantic Ocean. 


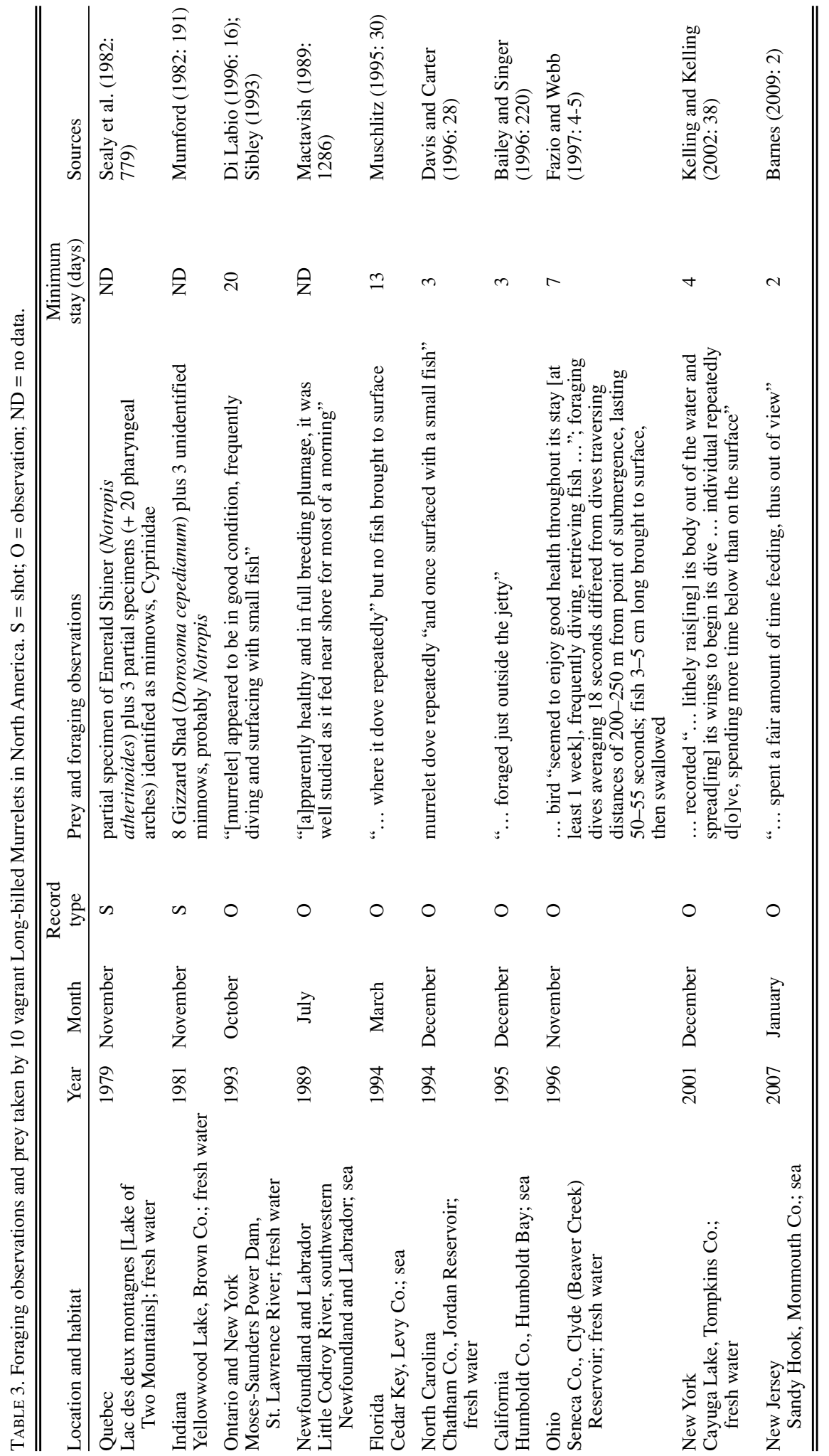


Some vagrant Long-billed Murrelets certainly survive for weeks during long-distance travel, even though survival of vagrants for more than a few days has traditionally been assumed to be low or zero (but see DeSante 1973; Newton 2008). Long-billed Murrelets may have stopped to feed along the west coast of the United States, whether they arrived directly from eastern Russia or returned from inland sites, and they may have survived for some time before and/or after being observed, as has been recorded for some other vagrant alcids (Sealy and Carter 2012). Once they replenished their reserves, some individuals on the west coast may have flown inland, continuing in the same (wrong) direction, that is, away from eastern Russia; some may have returned to eastern Russia. "Refuelled" individuals may have survived better inland or developed sufficient stores to attempt to return to Russia and possibly re-join Russian populations. On the other hand, those found dead or in poor condition inland may have flown non-stop from Asia and possibly landed because they were near death.

By highlighting these survival scenarios for the Long-billed Murrelet, we emphasize potential difficulties with interpreting our data, despite the relatively high number of occurrences of this species across North America. We could not directly determine routes used by individuals before or after being recorded in North America, but many individuals on the west coast apparently survived after observation, because only one dead Long-billed Murrelet was salvaged there (Table $2)$. In the absence of apparent direct lines of travel, determining exact routes and time required for individuals to fly from place to place will require use of satellite radios or GPS systems (e.g., Jouventin and Weimerskirch 1990; Landers et al. 2011). General routes and patterns of movements across North America, however, can be surmised by examining samples of records of vagrants (Sealy et al. 1991; Sealy and Carter 2012).

The proportion of individuals in a population that become vagrants (see Fraser 1997), and whether all die or some establish new populations or even return to their original breeding populations, is a gap in our understanding of mortality and population changes in species. For the Long-billed Murrelet, the relatively high degree of long-distance vagrancy in North America, exhibited only since 1979, is remarkable in comparison with other alcids and likely reflects changes in weather patterns that assist movements across the North Pacific Ocean, as well as changes in breeding habitats and populations in eastern Russia (see Carter et al. 2011). In addition, the ability of vagrant Longbilled Murrelets to survive for long periods enhances the chances of discovering vagrants in North America and increases the likelihood of moving long distances across the continent. Although this species is one of the rarest alcids, we do not consider the actual numbers of vagrant individuals recorded, even if we assume that all perish, to have a significant impact on the breeding population. We also do not know, however, how many individuals become vagrants but are not recorded.

A high level of vagrancy may reflect undetected population-level impacts being experienced in eastern Russia due to natural and anthropogenic factors, such as climate change, changes in prey and distribution of predators, and loss of coastal old-growth forests (Nelson et al. 2002). Ranges may change because pioneering individuals that were originally vagrants survive and breed successfully in new areas. Perhaps Long-billed Murrelets will breed in North America some day or possibly a few already have, without our knowledge, along the west coast where most birds have been observed and prey and forest habitat are similar to those of eastern Russia.

\section{Acknowledgements}

We thank the many birders and other field workers who carefully observed murrelets and recorded their behaviour, in some cases over several days, or salvaged dead and dying birds. Many individuals published their observations with detailed descriptions of the plumage, often accompanied by photographs, and notes on the condition of specimens, or information on habitat, weather conditions, and behaviour at the time of observation. Many workers responded to requests for additional details on body condition and prey of Long-billed Murrelets: R. Bowman, B. Di Labio, K. Garrett, J. Hudon, F. Huettmann, J. Kendall, K. McGowan, S. Mlodinow, B. Muschilitz, H. Nevins, W. Schmoker, P. Svingen, and G. van Vliet. Several museum curators and others provided additional information on specimens in their care: C. Angle (Smithsonian National Museum of Natural History), C. Cicero and N. Johnson (Museum of Vertebrate Zoology, University of California, Berkeley); A. Kratter (Florida Museum of Natural History, University of Florida, Gainesville); R. Johnson (Washington State University, Pullman); and H. Nevins (Moss Landing Marine Laboratory, Moss Landing, California). This work was funded by grants to SGS from the Natural Sciences and Engineering Research Council of Canada.

\section{Literature Cited}

Anderson, K. S. 1982. Marbled Murrelet: a first Massachusetts record. Bird Observer 10: 349-352.

Anderson, B. H. 1995. Eleventh report of the Florida Ornithological Society Records Committee. Florida Field Naturalist 23: 38-43.

Armistead, G. L., and M. J. Iliff. 2003. The vagrancy of Gray Kingbird in North America. North American Birds 57: 148-161.

Bailey, S. F., and D. Singer. 1996. Middle Pacific Coast. North American Birds 50: 218-220.

Barnes, S. 2009. New Jersey's first record of Long-billed Murrelet. New Jersey Birds 35: 2-3.

Carter, H. R., and J. L. Stein. 1995. Molts and plumages in the annual cycle of the Marbled Murrelet. Pages 99-109 
in Ecology and conservation of the Marbled Murrelet. Edited by C. J. Ralph, G. L. Hunt Jr., M. G. Raphael, and J. F. Piatt. U.S. Forest Service, General Technical Report PSW-GTR-152, Pacific Southwest Research Station, Albany, California. 420 pages.

Carter, H. R., S. K. Nelson, S. G. Sealy, and G. B. van Vliet. 2011. Occurrences of Kittlitz's Murrelets south of the breeding range along the west coast of North America. Northwestern Naturalist 92: 186-199.

Davis, R. 1995. Southern Atlantic Coast region. National Audubon Society Field Notes 49: 135-139.

Davis, R., and D. Carter. 1996. First record of Marbled Murrelet in North Carolina. Chat 60: 27-28.

DeSante, D. F. 1973. An analysis of the fall occurrences and nocturnal orientation of vagrant wood warblers (Parulidae) in California. Ph.D. dissertation, Stanford University, Palo Alto, California.

DeSante, D. F. 1983. Annual variability in the abundance of migrant landbirds on Southeast Farallon Island. Auk 100: 826-852.

DeSante, D. F., and D. G. Ainley. 1980. The avifauna of the South Farallon Islands, California. Studies in Avian Biology, Number 4. 104 pages.

Di Labio, B. M. 1996. First record of the Asiatic Marbled Murrelet in Ontario. Ontario Birds 14: 15-22.

Erickson, R. A., R. A. Hamilton, S. N. G. Howell, P. Pyle, and M. A. Patten. 1995. First record of the Marbled Murrelet and third record of the Ancient Murrelet for Mexico. Western Birds 26: 30-45.

Fazio, V. W., III, and D. Webb. 1997. A Long-billed Murrelet (Brachyramphus perdix) in Ohio. Ohio Cardinal 20: 1-6.

Fraser, P. A. 1997. How many rarities are we missing? Weekend bias and length of stay revisited. British Birds 90: 94101.

Friesen, V. L., J. F. Piatt, and A. J. Baker. 1996. Evidence from cytochrome $B$ sequences and allozymes for a 'new' species of alcid: the Long-billed Murrelet (Brachyramphus perdix). Condor 98: 681-690.

Gaston, A. J., and I. L. Jones. 1998. The Auks: Alcidae. Oxford University Press, Oxford, U.K. 349 pages.

Grinnell, J. 1922. The role of the "accidental." Auk 39: 373380.

Hoffman, W., and G. E. Woolfenden. 1988. A specimen of the Asiatic Marbled Murrelet from Florida. Florida Field Naturalist 16: 37-38.

Hopkins, D., D. Stone, and K. Rylands. 2006. The Longbilled Murrelet in Devon-a new British bird. Birding World 19: 457-464.

Jehl, D. R., and J. R. Jehl Jr. 1981. A North American record of the Asiatic Marbled Murrelet (Brachyramphus marmoratus perdix). American Birds 35: 911-912.

Jouventin, P., and H. Weimerskirch. 1990. Satellite tracking of Wandering Albatrosses. Nature 343: 746-748.

Kelling, S, and T. Kelling. 2002. Long-billed Murrelet (Brachyramphus perdix) at Ithaca, New York. Kingbird 52: 38-40.

Kondratyev, A. Ya., N. M. Litvinenko, Y. V. Shibaev, P. S. Vyatkin, and L. F. Kondratyeva. 2000. The breeding seabirds of the Russian Far East. Pages 37-81 in Seabirds of the Russian Far East. Edited by A. Y. Kondratyev, N. M. Litvinenko, and G. W. Kaiser. Special Publication, Canadian Wildlife Service, Environment Canada, Ottawa. 141 pages.
Konyukhov, N. B., and A. S. Kitaysky. 1995. The Asian race of the Marbled Murrelet. Pages 23-29 in Ecology and conservation of the Marbled Murrelet. Edited by C. J. Ralph, G. L. Hunt Jr., M. G. Raphael, and J. F. Piatt. U.S. Forest Service, General Technical Report PSW-GTR-152, Pacific Southwest Research Station, Albany, California. 420 pages.

Kratter, A. W., T. Webber, T. Taylor, and D. W. Steadman. 2002. New specimen-based records of Florida birds. Bulletin of the Florida Museum of Natural History 43: 111161.

Landers, T. J., M. J. Rayner, R. A. Phillips, and M. E. Hauber. 2011. Dynamics of seasonal movements by a trans-Pacific migrant, the Westland Petrel. Condor 113: 71-79.

Lethaby, N. 2000. The identification of Long-billed Murrelet in alternate plumage. Birding 32: 438-444.

Mactavish, B. 1989. Atlantic Provinces region. American Birds 43: 1285-1288.

Maumary, L., and P. Knaus. 2000. Marbled Murrelet in Switzerland: a Pacific Ocean auk new to the Western Palearctic. British Birds 93: 190-199.

Mlodinow, S. G. 1997. The Long-billed Murrelet (Brachyramphus perdix) in North America. Birding 29: 461-476.

Mumford, R. E. 1982. The Marbled Murrelet in Indiana. Indiana Audubon Quarterly 60: 190-191.

Muschlitz, B. P. 1995. Asiatic Marbled Murrelet: first spring record in North America. Florida Field Naturalist 23: 3032.

Nelson, S. K., Y. Fukuda, and N. Oka. 2002. The status and conservation of the Long-billed Murrelet in Japan. Journal of the Yamashina Institute for Ornithology 33: 88-106.

Newton, I. 2008. The migration of birds. Academic Press, New York. 976 pages.

Oka, N., and H. Hamasoto. 2001. Nutritional condition and muscular features of wintering Long-billed Murrelets in Japan. Condor 103: 874-878.

Patten M. A., and C. A. Marantz. 1996. Implications of vagrant southeastern vireos and warblers in California. Auk 113: 911-923.

Scott, W. B., and E. J. Crossman. 1973. Freshwater fishes of Canada. Fisheries Research Board of Canada, Ottawa, Ontario. Bulletin 184. 966 pages.

Sealy, S. G., and H. R. Carter. 2012. Rare inter-ocean vagrancy in Crested Auklet and Parakeet Auklet. Waterbirds 34: 64-73.

Sealy, S. G., H. R. Carter, and D. Alison. 1982. Occurrences of the Asiatic Marbled Murrelet (Brachyramphus marmoratus perdix [Pallas]) in North America. Auk 99: 778781.

Sealy, S. G., H. R. Carter, W. D. Shuford, K. D. Powers, and C. A. Chase III. 1991. Long-distance vagrancy of the Asiatic Marbled Murrelet. Western Birds 22: 145-155.

Sibley, D. 1993. An Asiatic Marbled Murrelet in Ontario. Birders Journal 2: 276-277.

Stejneger, L. 1886. On Brachyramphus perdix (Pall.) and its nearest allies. Zeitschrift für die Gesammte Ornithologie 3: 210-219.

Svingen, P. H. 2009. First Minnesota record of the Longbilled Murrelet (Brachyramphus perdix). Loon 81: 55-60.

Thompson, C. W., K. J. Pullen, R. E. Johnson, and E. B. Cummins. 2003. Specimen record of a Long-billed Murrelet from eastern Washington, with notes on plumage 
and morphometric differences between Long-billed and Marbled murrelets. Western Birds 34: 157-168.

Veit, R. R. 1997. Long-distance dispersal and population growth of the Yellow-headed Blackbird Xanthocephalus xanthocephalus. Ardea 85: 135-143.
Witt, W. C., M. S. Graus, and H. A. Walker. 2010. Molecular data confirm the first record of the Long-billed Murrelet for New Mexico. Western Birds 41: 160-167.

Received 29 November 2011

Accepted 9 May 2012 